\title{
Gambaran Kejadian Perdarahan Saluran Cerna pada Pasien Penyakit Ginjal Kronik di RSUP Dr. M. Djamil Padang
}

\author{
Asrining Tyas ${ }^{1}$, Saptino Miro², Ade Asyari ${ }^{3}$
}

\begin{abstract}
Abstrak
Penyakit Ginjal Kronik (PGK) dapat menyebabkan Perdarahan Saluran Cerna (PSC). Efek PSC sangat serius karena penurunan tekanan darah akibat perdarahan akan semakin menurunkan laju filtrasi glomerulus yang berarti semakin memperburuk PGK. Tujuan: Mengetahui kejadian PSC pada pasien PGK. Metode: Jenis penelitian ini adalah deskriptif dengan desain cross sectional menggunakan data rekam medis. Populasi penelitian adalah pasien PGK stadium 4 dan 5 rawat inap RSUP Dr. M. Djamil Padang periode Januari sampai Desember 2018. Teknik pengambilan sampel menggunakan simple random sampling. Sampel berjumlah 207 orang diambil dari populasi yang memenuhi kriteria inklusi dan eksklusi. Analisis data berupa analisis univariat dan disajikan dalam bentuk tabel distribusi. Hasil: Ada 11,6\% pasien PGK mengalami PSC. Persentase PSC lebih tinggi pada stadium 5 dibanding stadium 4 (11,8\%: 8,3\%), laki-laki dibanding perempuan (12,1\%:10,8\%), anemia dibanding tidak anemia (12,0\%: 0,0\%) dengan $100 \%$ pasien PGK yang mengalami PSC juga mengalami anemia, hemodialisis rutin dibanding nonhemodialisis rutin (12,7\%: 11,0\%), memiliki kadar ureum rerata 277,79 $\pm 134,92 \mathrm{mg} / \mathrm{dL}$, dan $100 \%$ mengalami PSC bagian atas dengan manifestasi terbanyak berupa melena $(41,7 \%)$.
\end{abstract}

Kata kunci: PGK, stadium, jenis kelamin, anemia, hemodialisis rutin, kadar ureum serum, perdarahan saluran cerna

\begin{abstract}
Chronic kidney disease (CKD) can cause gastrointestinal bleeding (Gl bleeding). The Gl bleeding effect is very serious because decrease in blood pressure due to bleeding will decrease the glomerular filtration rate, which means it worsens CKD. Objectives: To describe the incidence of GI bleeding in CKD patients. Methods: This research was descriptive with a cross sectional design using medical record data. The research population was patients with stage 4 and 5 CKD who were hospitalized at RSUP Dr. M. Djamil Padang during the period January until December 2018. The sampling technique used was simple random sampling. A sample of 207 people taken from populations that included in the inclusion and exclusion criteria. Data analysis used univariate analysis and presented by distribution tables. Results: This study showed $11.6 \%$ of CKD patients experienced a GI bleeding. The percentage of GI bleeding was higher in stage 5 than stage 4 (11.8\%: 8.3\%), male than female (12.1\%:10.8\%), anemia than non-anemia (12\%:0\%) with $100 \%$ CKD patients who experienced a Gl bleeding also anemia, routine hemodialysis than non-routine hemodialysis (12.7\% : 11\%), average urea level is $277.79+134.92 \mathrm{mg} / \mathrm{dL}$, and $100 \%$ experiencing upper GI bleeding with the most manifestations depending on melena (41.7\%).
\end{abstract}

Keywords: CKD, stadium, sex, age, anemia, routine hemodialysis, serum urea level, GI bleeding

Affiliasi penulis: 1. Prodi Pendidikan Dokter, Fakultas Kedokteran, Universitas Andalas, Padang, Indonesia. 2. Bagian IImu Penyakit Dalam, Fakultas Kedokteran, Universitas Andalas, Padang, Indonesia. 3. Bagian THT, Fakultas Kedokteran, Universitas Andalas, Padang, Indonesia /RSUP Dr. M. Djamil Padang.

Korespondensi: Saptino Miro,. Email: saptino_miro@yahoo.com Telp: 08126618933

\section{PENDAHULUAN}

Penyakit Ginjal Kronik (PGK) adalah keadaan klinis kerusakan struktur ataupun fungsi ginjal selama 3 bulan atau lebih dengan Laju Filtrasi Glomerulus (LFG) $<60 \mathrm{~mL} /$ menit/1,73 $\mathrm{m}^{2}$ dan dikatakan sudah mencapai tahap akhir jika LFG mencapai <15 $\mathrm{mL} / \mathrm{menit} 1,73 \mathrm{~m}^{2}$ dengan atau tidak dialisis. ${ }^{1}$ 
Penyakit ginjal kronik merupakan salah satu masalah kesehatan dunia karena kejadiannya terus bertambah, prognosis buruk, serta biaya pengobatan yang mahal. ${ }^{2}$ Sekitar satu dari sepuluh populasi global mengalami PGK pada stadium tertentu. Di dunia prevalensi PGK berkisar 11-13\% dengan prevalensi terbesar pada stadium $3 .^{3}$ Berdasarkan data Global Burden of Disease (GBD) tahun 2013, PGK telah menyebabkan hampir satu juta kematian di seluruh dunia dan merupakan penyebab kematian ke-13, hal ini menunjukkan peningkatan yang sangat signifikan dibandingkan tahun 1990 yang berada pada urutan ke-27. ${ }^{4}$ Di Indonesia sendiri prevalensi PGK sebesar $0,2 \%$ dan menempati peringkat ke-10 (3\%) penyebab kematian di Indonesia. ${ }^{5}$ Data dari Kementerian Kesehatan tahun 2013, prevalensi PGK di Sumatera Barat sebesar 0,2\%. Prevalensi PGK tertinggi sebesar 0,4\% yaitu di Kabupaten Tanah Datar dan Kota Solok. Di Kota Padang didapatkan prevalensi PGK sebesar $0,3 \% .^{6}$

Penyakit ginjal kronik dapat menyebabkan berbagai manifestasi klinis, salah satunya adalah gangguan saluran cerna. Manifestasi gangguan saluran cerna dapat berupa nausea, vomitus, nyeri abdomen, diare, konstipasi, serta perdarahan. Gangguan saluran cerna akan menganggu asupan gizi yang pada akhirnya berkaitan dengan malnutrisi, hal ini meningkatkan morbiditas dan mortalitas pada pasien PGK. ${ }^{7}$

Salah satu gangguan pada saluran cerna yang sering ditemukan akibat komplikasi PGK adalah perdarahan. Insidens dan mortalitas Perdarahan Saluran Cerna (PSC) pada pasien PGK lebih tinggi dibandingkan pada populasi umum. ${ }^{7}$ Pada populasi umum, dari total 398.213 pasien dengan diagnosis PSC, 35.985 (9\%) pasien PGK; 14.983 (3,7\%) penyakit ginjal tahap akhir atau ESRD (End Stage Renal Disease); dan 347.245 (87,2\%) di kelompok penyakit non-ginjal. ${ }^{8}$ Sedangkan pada pasien PGK stadium 3-5, dari total 2.968 pasien didapatkan 386 (13\%) mengalami PSC. ${ }^{9}$

Efek PSC sangat serius karena penurunan tekanan darah akibat perdarahan akan semakin menurunkan LFG yang berarti semakin memperburuk PGK. ${ }^{10}$ Selain itu, PSC juga menimbulkan komplikasi lain seperti malnutrisi dan anemia. ${ }^{11}$ Anemia akibat
PSC tersebut dapat menyebabkan penyakit jantung iskemik ataupun gagal jantung yang pada akhirnya berujung ke kematian. ${ }^{12}$ Oleh karena itu, PSC pada pasien PGK perlu mendapat perhatian.

Patogenesis PSC pada PGK masih belum jelas dan bersifat multifaktorial. Diduga faktor yang berperan terhadap PSC pada PGK disebabkan karena penggunaan antitrombosit dan antikoagulan; heparinisasi pada saat dialisis; prosedur operasi; serta efek uremia terhadap mukosa saluran cerna, disfungsi trombosit, dan eritrosit. ${ }^{13}$

Fungsi residual ginjal yang tidak adekuat, maka terjadi peningkatan kadar ureum serum pada pasien PGK. Pasien dengan kadar ureum serum yang tinggi (pasien uremia) memiliki risiko perdarahan yang tinggi pula, hal ini disebabkan oleh karena toksin ureum akan mengubah fungsi trombosit dan eritrosit. Perdarahan oleh karena efek ureum serum yang meningkat disebut uremic bleeding. Walaupun terdapat beberapa teori yang menjelaskan mekanisme uremic bleeding, patogenesis uremic bleeding pada PSC masih belum jelas. ${ }^{14}$

Hemodialis (HD) rutin juga dapat menyebabkan PSC, hal ini dikarenakan penggunaan antikoagulan dan heparinisasi saat HD. ${ }^{15}$ Selain itu, pasien yang menjalani perawatan HD juga kehilangan zat besi berkaitan dengan prosedur iatrogenik, sehingga akhirnya menyebabkan anemia. Anemia sendiri dapat menyebabkan PSC. ${ }^{16}$

Berdasarkan uraian di atas, peneliti merasa penting melakukan penelitian mengenai gambaran kejadian PSC pada pasien PGK. Diharapkan kedepannya penelitian ini dapat berkonstribusi sebagai bahan evaluasi serta meningkatkan kewaspadaan klinisi dalam perencanaan dan pengelolaan pasien PGK agar tidak menimbulkan komplikasi PSC.

\section{METODE}

Jenis penelitian ini adalah deskriptif dengan desain cross sectional. Penelitian dilaksanakan di instalasi rekam medis RSUP Dr. M. Djamil Padang pada bulan Januari sampai Mei 2019. Penelitian ini dilakukan untuk mengetahui gambaran kejadian PSC pada pasien PGK. 
Populasi penelitian ini adalah semua pasien PGK stadium 4 dan 5 rawat inap RSUP Dr. M. Djamil Padang periode Januari-Desember 2018. Sampel minimal pada penelitian ini adalah 174 orang yang memenuhi kriteria inklusi dan eksklusi. Kriteria Inklusi: Pasien PGK stadium 4 dan 5 yang mengalami PSC maupun yang tidak mengalami PSC selama menderita PGK pada bulan Januari-Desember 2018. Kriteria Eksklusi: Pasien PGK dengan catatan medis tidak lengkap, yaitu nama, stadium PGK, jenis kelamin, kadar $\mathrm{Hb}$ (untuk menentukan anemia atau tidak), HD rutin atau tidak, kadar ureum serum, serta manifestasi PSC. rumus: ${ }^{17}$

Besar sampel minimal ditentukan dengan

Keterangan:

$$
n=\frac{\mathrm{Z} \alpha^{2} P Q}{d^{2}}
$$

$\mathrm{n}=$ jumlah subjek

$\mathrm{Z} \alpha=$ deviat baku alfa $(1,96)$

$\mathrm{P}=$ proporsi kejadian variabel yang diteliti $(13 \%)^{9}$

$Q=1-P$

$d=$ Presisi $(0,05)$

Berdasarkan rumus di atas didapatkan sampel minimal adalah 174 orang. Teknik pengambilan sampel menggunakan simple random sampling pada 395 pasien PGK stadium 4 dan 5 rawat inap RSUP Dr. M. Djamil Padang periode Januari-Desember 2018. Diambil 207 orang sebagai sampel yang memenuhi kriteria inklusi dan eksklusi.

\section{HASIL}

Penelitian ini dilakukan di instalasi rekam medik RSUP Dr. M. Djamil Padang pada bulan Januari-Mei 2019. Sampel pada penelitian ini berjumlah 207 orang pasien PGK stadium 4 dan 5 rawat inap yang memenuhi kriteria inklusi dan eksklusi yang diambil menggunakan teknik simple random sampling dari total 395 orang populasi. Data hasil penelitian dikumpulkan dan dianalisis meliputi analisis univariat dan disajikan dalam bentuk tabel distribusi. Analisis univariat digunakan untuk melihat distribusi frekuensi variabel yang diteliti berupa stadium PGK, jenis kelamin, kadar $\mathrm{Hb}$ (anemia atau tidak), HD rutin atau tidak, kadar ureum serum, serta manifestasi PSC yang berkaitan dengan kejadian PSC pada pasien PGK.
Tabel 1. Distribusi frekuensi kejadian PSC pada pasien PGK

\begin{tabular}{lll}
\hline Kejadian PSC & \multicolumn{2}{c}{$\mathbf{n}(\%)$} \\
\hline Ya & 24 & $(11,6)$ \\
& 183 & $(88,4)$ \\
\hline Total & 207 & $(100,0)$ \\
\hline
\end{tabular}

Tabel 1 memperlihatkan angka kejadian PSC pada pasien PGK sebanyak 24 orang (11,6\%) dari 207 orang sampel yang diteliti.

Tabel 2. Distribusi frekuensi kejadian PSC pada pasien PGK berdasarkan stadium, jenis kelamin, kejadian anemia, dan HD rutin

\begin{tabular}{|c|c|c|c|}
\hline \multirow[b]{2}{*}{ Karakteristik } & \multicolumn{2}{|c|}{ PSC } & \multirow{2}{*}{$\begin{array}{l}\text { Total } \\
\text { n (\%) }\end{array}$} \\
\hline & $\begin{array}{c}\text { Ya } \\
\text { n (\%) }\end{array}$ & $\begin{array}{l}\text { Tidak } \\
\text { n (\%) }\end{array}$ & \\
\hline \multicolumn{4}{|l|}{ Stadium } \\
\hline 4 & $1 \quad(8,3)$ & $11 \quad(91,7)$ & $12(100)$ \\
\hline 5 & $23(11,8)$ & $172(88,2)$ & $195(100)$ \\
\hline \multicolumn{4}{|l|}{ Jenis Kelamin } \\
\hline Laki-laki & $15(12,1)$ & $109(87,9)$ & $124(100)$ \\
\hline Perempuan & $9(10,8)$ & ?) & 83 (100) \\
\hline \multicolumn{4}{|l|}{ Kejadian Anemia } \\
\hline $\mathrm{Ya}$ & $24(12,0)$ & $176(88,0)$ & $200(100)$ \\
\hline Tidak & $0 \quad(0,0)$ & $7 \quad(100,0)$ & $7 \quad(100)$ \\
\hline \multicolumn{4}{|l|}{ HD Rutin } \\
\hline $\mathrm{Ya}$ & $14(12,7)$ & $102(87,3)$ & $116(100)$ \\
\hline Tidak & $10(11,0)$ & $81 \quad(89,0)$ & 91 (100) \\
\hline
\end{tabular}

Tabel 2 memperlihatkan bahwa persentase kejadian PSC pada pasien PGK lebih tinggi pada stadium 5, jenis kelamin laki-laki, mengalami anemia (100\% pasien PGK yang mengalami PSC juga mengalmi anemia), dan menjalani HD rutin.

Tabel 3. Kadar rerata ureum serum pada pasien PGK yang mengalami PSC

\begin{tabular}{cccc}
\hline PSC & Rerata \pm SD & Min & Maks \\
\hline Ya & $277,79 \pm 134,92$ & 114 & 573 \\
Tidak & $176,27 \pm 103,17$ & 12 & 535 \\
\hline
\end{tabular}

Tabel 3 memperlihatkan bahwa pasien PGK yang mengalami PSC memiliki kadar rerata ureum serum $277,79 \pm 134,92 \mathrm{mg} / \mathrm{dL}$ sedangkan pasien yang tidak mengalami PSC 176,27 $\pm 103,17 \mathrm{mg} / \mathrm{dL}$. 
Tabel 4. Distribusi frekuensi manifestasi klinis kejadian PSC pada pasien PGK

\begin{tabular}{|c|c|c|}
\hline \multirow{2}{*}{$\begin{array}{l}\text { Manifestasi Klinis PSC } \\
\text { Sumber PSC }\end{array}$} & \multicolumn{2}{|c|}{ n (\%) } \\
\hline & & \\
\hline \multirow[t]{2}{*}{ Atas } & \multicolumn{2}{|c|}{$24(100,0)$} \\
\hline & 0 & $(0,0)$ \\
\hline \multicolumn{3}{|l|}{ Jenis PSC } \\
\hline Hematemesis & 5 & $(20,8)$ \\
\hline Melena & 10 & $(41,7)$ \\
\hline Hematemesis + Melena & 9 & $(37,5)$ \\
\hline Hematokezia & 0 & $(0,0)$ \\
\hline Total & \multicolumn{2}{|c|}{$24(100,0)$} \\
\hline
\end{tabular}

Tabel 4 memperlihatkan sumber PSC pada pasien PGK yang mengalami PSC 100\% disebabkan saluran cerna bagian atas (SCBA) dengan manifestasi terbanyak berupa melena $(41,7 \%)$.

\section{PEMBAHASAN}

\section{Distribusi Frekuensi Kejadian PSC pada Pasien PGK}

Penelitian ini mendapatkan hasil bahwa kejadian PSC pada pasien PGK sebesar 11,6\%. Hal ini tidak jauh berbeda dari penelitian Liang et a/ di Cina pada tahun 2014 yang mendapatkan hasil sebesar 13\%. ${ }^{9}$ Penelitian Sood et al mengenai PSC pada pasien PGK pada tahun 2012 mendapatkan hasil sebesar $9 \%{ }^{8}$

Diduga faktor yang berperan terhadap PSC pada pasien PGK disebabkan karena penggunaan antitrombosit dan antikoagulan; heparinisasi pada saat dialisis; prosedur operasi; serta efek uremia terhadap mukosa saluran cerna, disfungsi trombosit, dan eritrosit. ${ }^{13}$

Hemodialis rutin juga dapat menyebabkan PSC, hal ini dikarenakan penggunaan antikoagulan dan heparinisasi saat HD. ${ }^{15}$ Selain itu, pasien yang menjalani perawatan HD juga kehilangan zat besi berkaitan dengan prosedur iatrogenik, sehingga akhirnya menyebabkan anemia. Anemia sendiri dapat menyebabkan PSC. ${ }^{16}$

\section{Gambaran Kejadian PSC pada Pasien PGK Berdasarkan Stadium 4 dan 5}

Penelitian ini mendapatkan hasil bahwa persentase kejadian PSC pada pasien PGK lebih tinggi pada stadium 5 dibanding stadium $4(11,8 \%$ : $8,3 \%)$.

Penelitian ini tidak jauh berbeda dengan penelitian Liang et al pada tahun 2014 di China yang mendapatkan kejadian PSC pada pasien PGK 3,7\% pada stadium 3; $5 \%$ pada stadium 4; dan $13,9 \%$ pada stadium 5. ${ }^{9}$ Penelitian Hwang et al di Korea tahun 2012 mendapatkan hasil 36,5\% stadium 3, 25\% stadium 4, dan 38,5\% stadium 5 (Pasien PGK stadium 5 memiliki risiko 4,1 kali lipat lebih besar mengalami PSC dibandingkan pasien PGK stadium 3 dan 4). ${ }^{18}$

Perdarahan saluran cerna lebih sering pada pasien PGK stadium 5 dibanding pasien PGK stadium 3 atau 4. Temuan ini menunjukkan hubungan antara tingkat uremia dan cedera mukosa saluran cerna. ${ }^{18}$ Penelitian Liang menunjukkan bahwa setiap 5 $\mathrm{mL} / \mathrm{menit} / 1,73 \mathrm{~m}^{2}$ peningkatan LFG dikaitkan dengan risiko PSC $10 \%$ lebih rendah. ${ }^{9}$

Mekanisme fisiologis yang berkontribusi terhadap kecenderungan perdarahan meningkat pada pasien PGK stadium 5 termasuk uremia yang menyebabkan disfungsi trombosit, penggunaan heparin intermiten di dialisis (stadium 5 lebih banyak menjalani dialisis dibanding stadium lain), serta penggunaan agen antitrombosit dan antikoagulan. ${ }^{19}$

\section{Gambaran Kejadian PSC pada Pasien PGK Berdasarkan Jenis Kelamin}

Penelitian ini mendapatkan hasil bahwa persentase kejadian PSC pada pasien PGK lebih tinggi pada laki-laki dibanding perempuan $(12,1 \%$ : $10,8 \%$ ).

Penelitian Wasse et al di Amerika tahun 2003 dari 5.576 laki-laki, 367 (6,58\%) mengalami PSC dan dari 5.266 perempuan 331 orang $(6,29 \%)$ mengalami PSC. ${ }^{20}$ Penelitian Sotoudehmanesh et al di Iran tahun 2002 dari 124 laki-laki dan 82 perempuan dengan menggunakan analisis regresi multivariate didapatkan bahwa pasien laki-laki 2,24 kali lebih banyak mengalami PSC daripada perempuan. ${ }^{21}$

Berbeda dengan penelitian Trivedi et al di Amerika pada 406.836 pasien didapatkan 133.967 mengalami PSC, dengan 66140 (49,37\%) laki-laki dan 67827 (50,63\%) perempuan. ${ }^{15}$ Penelitian Trivedi menunjukkan perempuan lebih banyak mengalami 
PSC dibanding laki-laki. Penelitian Luo et al di Taiwan tahun 2011 juga mendapatkan hasil bahwa hazard rasio perempuan lebih besar mengalami perdarahan dibanding laki-laki. Prediktor PSC pada laki-laki adalah 4,54 sedangkan perempuan sebesar $6,15 .^{22}$

Mekanisme kerja estrogen menurunkan kejadian perdarahan belum sepenuhnya dipahami. Namun, estrogen terkonjugasi dapat mengurangi waktu perdarahan dengan mengurangi L-arginin yang merupakan prekursor NO. NO adalah penghambat agregasi trombosit yang diproduksi oleh sel endotel dan trombosit. Oleh sebab itu, penurunan L-arginin dapat meningkatkan pembentukan trombosit dan akhirnya mengurangi perdarahan. ${ }^{23}$

Penelitian lain menyebutkan bahwa estrogen terbukti mempersingkat waktu perdarahan dan peningkatan pembentukan tromboksan dan Bthromboglobulin di mikrovaskular, namun tidak ada efek pada pengurangan prostasiklin. Hal ini menunjukkan bahwa estrogen dapat meningkatkan reaktivitas trombosit daripada mengurangi produksi prostasiklin endotel. ${ }^{24}$

\section{Gambaran Kejadian PSC pada Pasien PGK Berdasarkan Anemia atau Tidak}

Penelitian ini mendapatkan hasil bahwa persentase kejadian PSC pada pasien PGK lebih tinggi pada anemia dibanding non-anemia (12,0\% : 0,0\%). Penelitian ini juga mendapatkan hasil bahwa $100 \%$ pasien PGK yang mengalami PSC juga mengalami anemia.

Penelitian Agudo et al di Spanyol tahun 2019 pada 9.658 pasien PGK, didapatkan $100 \%$ pasien PGK yang mengalami PSC juga mengalami anemia. ${ }^{25}$ Penelitian Marinescu et al di Romania tahun 2016 pada 30 pasien PGK yang mengalami PSC, seluruhnya (100\%) mengalami anemia dengan kadar $\mathrm{Hb}$ terbanyak adalah 8 - $10 \mathrm{~g} / \mathrm{dL}(33,3 \%) .{ }^{26}$

Studi reologi telah menunjukkan bahwa dalam keadaan normal, aliran laminar eritrosit cenderung di tengah-tengah lumen pembuluh darah. Massa eritrosit memberikan tekanan radial ke luar pada plasma sekitarnya sehingga trombosit berjalan dekat dengan dinding pembuluh darah. Jika hematokrit berkurang, trombosit berjalan lebih dekat ke pusat lumen pembuluh darah, dengan demikian menurunkan interaksi trombosit dengan subendotelium. ${ }^{8}$ Selain oleh efek mekanik, eritrosit juga melepasakan ADP dan TXA2 yang meningkatkan agregasi trombosit. Ketika eritrosit berkurang maka produksi ADP dan tromboksan akan ikut berkurang, agregasi trombosit juga akan berkurang. $\mathrm{Hb}$ juga mengikat $\mathrm{NO}$ dan prostasiklin oleh karena itu jika hematokrit berkurang maka akan tejadi peningkatan aktivitas NO dan prostasiklin yang bebas, efeknya dalah penghambatan agregasi trombosit dan terjadi vasodilatasi. ${ }^{13}$

\section{Gambaran Kejadian PSC pada Pasien PGK Berdasarkan HD Rutin}

Penelitian ini mendapatkan hasil bahwa persentase kejadian PSC pada pasien PGK lebih tinggi pada hemodialisis rutin dibanding nonhemodialisis rutin (12,7\%: 11,0\%).

Penelitian ini tidak jauh berbeda dengan penelitian Marinescu et al di Romania tahun 2016 pada 30 pasien PGK yang mengalami PSC, 16 orang (53,33\%) menjalani HD dan hanya 14 orang (46,67\%) yang tidak menjalani HD. ${ }^{26}$ Penelitian Luo et al di Taiwan tahun 2011 pada 78.828 orang yang diteliti, $3.004(3,8 \%)$ pasien mengalami PSC. Dari jumlah tersebut 2.361 PGK dialisis $(6,5 \%$ dari total pasien yang menjalani dialisis), 163 PGK non-dialisis $(2,6 \%$ dari total pasien PGK non-dialisis), 480 kontrol (1,3\% dari total pasien kontrol). Menggunakan Kapln-Meier analisis, terlihat pasien PGK dengan dialisis mempunyai risiko lebih tinggi mengalami PSC dibanding PGK non-dialisis dan pasien PGK nondialisis lebih besar risiko perdarahan dibanding kontrol. ${ }^{22}$

Faktor-faktor penyebab meningkatnya insiden PSC pada pasien dialisis jangka panjang masih belum jelas. Sekitar 2/3 pasien HD rutin ditemukan heparin pada plasma pre-dialisis, hal ini menunjukkan penggunaan antikoagulan kronik. ${ }^{15}$

Anemia juga dapat menyebabkan PSC. Pada pasien yang menjalani perawatan HD, kehilangan zat besi (hingga akhirnya menyebabkan anemia) berkaitan dengan prosedur iatrogenik, seperti kehilangan darah di dializer, pengambilan sampel darah, perdarahan dari fistula arteriovenosa, serta paparan berulang bedah vaskuler untuk perbaikan atau pembuatan akses vaskular baru untuk dialisis. ${ }^{16}$ 


\section{Gambaran Kejadian PSC pada Pasien PGK Berdasarkan Kadar Ureum Serum}

Penelitian ini mendapatkan kadar ureum ratarata pasien PGK yang mengalami PSC adalah 277,79 $\pm 134,92 \mathrm{mg} / \mathrm{dL}$, sedangkan pada pasien yang tidak mengalami PSC adalah 176,27 $\pm 103,17 \mathrm{mg} / \mathrm{dL}$. Terlihat bahwa pasien PGK yang mengalami PSC memiliki kadar ureum yang lebih tinggi.

Penelitian Agudo et al di Spanyol menunjukkan rerata kadar ureum pasien PGK yang mengalami PSC adalah $83,9 \pm 42,9 \mathrm{mg} / \mathrm{dL}$, sedangkan pasien yang tidak mengalami PSC adalah 78,9 \pm 40,6 mg/dL. Pasien dengan uremia $>50 \mathrm{mg} / \mathrm{dL}$ mengalami pedarahan saluran cerna sebesar $27,8 \%$, sedangkan yang tidak mengalami PSC hanya $4,8 \% .{ }^{25}$ Penelitian Liang et al di Cina tahun 2014 rata-rata kadar ureum pasien PGK yang mengalami PSC adalah $49 \pm 38$ $\mathrm{mg} / \mathrm{dL}$, sedangkan pasien yang tidak mengalami PSC adalah $42 \pm 38 \mathrm{mg} / \mathrm{dL}$. Terlihat bahwa pasien PGK yang mengalami PSC memiliki kadar ureum yang lebih tinggi. $^{9}$

Ureum berlebih dapat menyebabkan anemia pada pasien PGK, anemia sendiri dapat menyebabkan PSC. Hal-hal yang menyebabkan anemia oleh karena ureum serum yang meningkat, diantaranya: diperkirakan bahwa uremia mencegah penyerapan besi di usus. ${ }^{27}$ Sebuah studi prospektif antara pemberian besi oral dan besi secara IV pada pasien PGK dengan anemia defisiensi besi, zat besi oral tidak efektif dalam meningkatkan kadar $\mathrm{Hb}$ pasien, tapi besi IV terlihat memberikan hasil yang baik dengan kenaikan rata-rata $\mathrm{Hb}<7 \mathrm{~g} / \mathrm{dL}$ menjadi $>12 \mathrm{~g} / \mathrm{dL} .{ }^{16}$ Selain itu, telah terbukti bahwa toksin uremia juga dapat menginaktifkan eritropoietin atau menekan respon sumsum tulang terhadap eritropoietin, serta pendeknya masa hidup eritrosit akibat kondisi uremia. $^{10}$

Terdapatnya zat uremia yang mengganggu hemostatis dalam plasma telah didalilkan sebagai mekanisme untuk uremic bleeding. Beberapa zat menghambat fungsi trombosit pada plasma uremia yaitu urea dan asam guanidinosuccunic. Substansi ini menjadi inhibitor adhesi dan agregasi trombosit dengan cara menempel pada reseptor GPIlb-IIla, sehingga menghalangi vWF dan fibrinogen berikatan dengan reseptor GPIIb-IIla. Subtansi ini terakumulasi pada pasien PGK karena berkurangnya laju pembersihan ginjal dan mengalami perbaikan setelah dilakukan dialisis yang efektif. ${ }^{13}$

Trombosit uremia memproduksi lebih banyak prostasiklin dan NO dari pada trombosit non-uremia. Prostasiklin adalah inhibitor ampuh dalam agregasi trombosit, merupakan metabolit dari jalur arakidonat. Modulator yang paling penting dari produksi siklik adenosine monofosfat (cAMP) adalah prostasiklin, jumlah CAMP juga meningkat pada pasien dengan PGK. Peningkatan cAMP menggaggu pelepasan PIP2 dan mengubah mobilisasi kalsium sehingga TXA2 dan ADP berkurang. ${ }^{13}$

Uremia juga dapat meningkatkan produksi asam lambung sehingga menyebabkan hipergastrinemia. Uremia dan asam asetilsalisilat diidentifikasi sebagai faktor risiko untuk lesi mukosa lambung akut. ${ }^{25}$ Hipergastrinemia pada PGK terjadi karena stres psikologis penyakit, berkurangnya bersihan hormon gastrin sebagai akibat penurunan LFG, dan bisa juga karena mekanisme umpan balik dari asam lambung untuk menetralisir amonia pada lambung, pemecahan ureum menjadi amonia tinggi terjadi pada mukosa lambung pada pasien PGK. ${ }^{28}$ Faktor lain adalah tingginya prevalensi refluks empedu dan menurunnya sekresi bikarbonat oleh pancreas yang terlihat pada pasien uremia. ${ }^{21}$

\section{Gambaran Manifestasi Klinis Kejadian PSC pada Pasien PGK}

Penelitian ini mendapatkan hasil bahwa dari 24 pasien PGK yang mengalami PSC 100\% adalah perdarahan SCBA berupa melena (41,67\%), hematemesis + melena $(37,5 \%)$, dan hematemesis $(20,83 \%)$. Perdarahan SCBB tidak ditemukan pada penelitian ini. Terlihat bahwa melena merupakan manifestasi klinis terbanyak PSC pada pasien PGK dibanding hematemesis + melena ataupun hematemesis saja.

Penelitian Marinescu et al di Romania tahun 2016 pada 30 pasien yang mengalami PSC, 21 pasien (70\%) mengalami melena, 5 pasien (16,7\%) mengalami hematemesis dan melena, dan 4 orang $(13,3 \%)$ mengalami hematemesis saja. ${ }^{26}$ Penelitian Lepere et al di Pakistan tahun 2005 dari 182 pasien yang mengalami perdarahan saluan cerna, 104 pasien 
(57\%\%) mengalami melena, 47 pasien (26\%) mengalami hematokezia, dan 31 pasien (17\%) mengalami hematemesis + hematokezia. ${ }^{29}$ Penelitian Trivedi et al di Amerika tahun 2014 pada 133.967 pasien yang mengalami PSC, perdarahan SCBA juga lebih banyak ditemukan $(65,2$ kejadian/1000 pasien/tahun) dibanding perdarahan SCBB (33,7 kejadian/1000 pasien/tahun). Tukak lambung adalah penyebab terbanyak pada perdarahan SCBA (6,4\%) dan diverticulosis kolon pada perdarahan SCBB $(6,2 \%) .{ }^{15}$

Melena adalah gejala yang paling umum dari PSC bagian atas (terutama lambung). Hematemesis menunjukkan adanya perdarahan besar di saluran cerna bagian atas. Dalam satu penelitian, 6 pasien dengan hematemesis kehilangan lebih dari seperempat volume eritrosit mereka. Banyaknya hematemesis memberikan indikasi lebih lanjut tentang tingkat perdarahan. ${ }^{30}$ Hematokezia (bagian dari PSC bagian bawah) 14\% disebabkan oleh hemoroid. Hemoroid meningkat pada populasi dialisis peritoneal karena peningkatan tekanan intra-abdomen selama dialisis peritoneal. ${ }^{19}$

Hal ini sesuai dengan Penelitian Agudo et al di Spanyol tahun 2019 pada 198 pasien dengan PSC, prevalensi lesi saluran cerna dengan endoskopi yang paling umum adalah gastritis kronis (50\%), ulkus lambung dan duodenum (17,7\%), lesi preneoplastic $(43,9 \%)$, lesi akut mukosa lambung (22, 6\%), diverticulosis $(21,5 \%)$ dan angiodysplasias (14,4\%), hemoroid $(27,5 \%) .{ }^{25}$

Oleh karena itu manifestasi perdarahan yang paling banyak ditemukan adalah melena, diikuti hematemesis + melena, hematemesis, dan tidak ditemukan hematokezia karena pada penelitian ini pasien menjalani dialisis berupa HD bukan dialsisis peritoneal.

\section{SIMPULAN}

Pasien PGK yang mengalami PSC memiliki kadar rerata ureum serum lebih tinggi dibanding yang tidak mengalami PSC, dan manifestasi klinis terbanyak adalah PSC bagian atas berupa melena.

\section{SARAN}

Perlu dilakukan penelitian lebih lanjut mengenai analisis kejadian PSC pada pasien PGK dengan variabel lain yang tidak diteliti pada penelitian ini, seperti riwayat merokok, konsumsi alkohol, aktivitas fisik, penggunaan obat antikoagulan lain, dan infeksi Helicobacter pylori.

\section{UCAPAN TERIMAKASIH}

Terimakasih kepada semua pihak yang memberikan arahan, bimbingan, serta motivasi terhadap penelitian ini.

\section{DAFTAR PUSTAKA}

1. Arifa SI, Azam M, Handayani OWK. Faktor yang berhubungan dengan kejadian penyakit ginjal kronik pada penderita hipertensi di Indonesia. J MKMI. 2017;13(4):319-28

2. InfoDATIN Pusat Data dan Informasi Kementerian Kesehatan RI. Situasi Penyakit Ginjal Kronik. Jakarta: Kementerian Kesehatan RI; 2017.1-2.

3. Hill NR, Fatoba ST, Oke JL, Hirst JA, O'Callaghan $\mathrm{CA}$, Lasserson DS, et al. Global prevalence of chronic kidney disease - a systematic review and meta-analysis. PLoS One. 2016;11(7):1-18.

4. Naghavi $M$, Wang $H$, Lozano $R$, Davis $A$, Liang $X$, Zhoul M, et al. Global, regional, and national agesex specific all-cause and cause-specific mortality for 240 causes of death, 1990-2013: a systematic analysis for the Global Burden of Disease Study 2013. Lancet. 2015;385(9963):117-71.

5. Badan Penelitian dan Pengembangan Kesehatan. Riset Kesehatan Dasar (RISKESDAS) Laporan Nasional 2013. Jakarta: Kementerian Kesehatan $\mathrm{RI} ; 2013$.

6. Kementerian Kesehatan RI. Profil kesehatan Indonesia tahun 2013. Jakarta: Kementerian Kesehatan RI; 2014.hlm.507.

7. Pardede DKB. Gangguan gastrointestinal pada penyakit ginjal kronik. CDK Journal. 2012;39(7):501-7.

8. Sood P, Kumar G, Nanchal R, Sakhuja A, Ahmad $\mathrm{S}$, Ali $\mathrm{M}$, et al. Chronic kidney disease and end- 
stage renal disease predict higher risk of mortality in patients with primary upper gastrointestinal bleeding. Am J of Nephrol. 2012;35(3),216-24.

9. Liang CC, Wang SM, Kuo HL, Chang CT, Liu JH, Lin $\mathrm{HH}$, et al. Upper gastrointestinal bleeding in patients with CKD. Clin J Am Soc Nephrol. 2014; 9(8): 1354-9.

10. Wilson LM. Gagal Ginjal Kronik. In : Hartanto H, Wulansari $P$, Susi $N$, Mahanani DA, editors. Patofisiologi konsep klinis proses-proses penyakit. Volume 2. Edisi ke-6. Jakarta: EGC; 2012.hlm. 954-6.

11. Grooteman KV, Geenen EMJV, Kievit W, Drenth $\mathrm{JPH}$. Chronic anemia due to gastrointestinal bleeding: when do gastroenterologists transfuse? United European Gastroenterol J. 2017;5(7):96773.

12. Pardede SO, Chunnaedy S. Penyakit ginjal kronik pada anak. Jurnal Sari Pediatri. 2009;11(3):199203.

13. Sohal AS, Gangji AS, Crowther MA, Treleaven D. Uremic bleeding: pathophysiology and clinical risk factors. Thromb Res. 2006;118(3):417-22.

14. Lai YC, Tarng DC. Hemorrhagic acalculous cholecystitis: an unusual location of uremic bleeding. J Chin Med Assoc. 2009;72(9):484-7.

15. Trivedi H, Yang J, Szabo A. Gastrointestinal bleeding in patients on long-term dialysis. J Nephrol. 2014; 28(2):235-43.

16. Fudin R, Jaichenko J, Shostak A, Bennett $M$, Gotloib L. Correction of uremic iron deficiency anemia in hemodialyzed patients: a prospective study. Nephron. 1998;79(3):299-305.

17. Dahlan MS. Besar sampel dan cara pengambilan sampel dalam penelitian kedokteran dan kesehatan. Edisi ke-3. Jakarta: Salemba Medika; 2010.hIm.36.

18. Hwang HS, Song YM, Kim EO, Koh ES, Yoon HE, Chung SJ, et al. Decisive indicator for gastrointestinal workup in anemic patients with nondialysis chronic kidney disease. Int J Med Sci. 2012;9(8):634-41.

19. Saeed F, Agrawal N, Greenberg E, Holley JL.
Lower gastrointestinal bleeding in chronic hemodialysis patients. Int J Nephrol. 2011:1-8.

20. Wasse H, Gillen DL, Ball AM, Kestenbaum BR, Seliger SL, Sherrard D, et al. Risk factors for upper gastrointestinal bleeding among end-stage renal disease patients. Kidney Int. 2003;64(4):1455-61.

21. Sotoudehmanesh R, Asgari AA, Ansari R, Nouraie $M$. Endoscopic findings in end-stage renal disease. Endoscopy. 2003;35(6):502-5.

22. Luo JC, Leu HB, Huang KW, Huang CC, Hou MC, Lin $\mathrm{HC}$, et al. Incidence of bleeding from gastroduodenal ulcers in patients with end-stage renal disease receiving hemodialysis. CMAJ. 2011;183(18),1345-51.

23. Gonzalez J, Bryant S, Hermes-DeSantis ER. Transdermal estradiol for the management of refractory uremic bleeding. Am J Health Syst Pharm. 2018;75(9):177-83.

24. Heistinger M, Stockenhuber F, Schneider B, Pabinger I, Brenner B, Wagner B, et al. Effect of conjugated estrogens on platelet function and prostacyclin generation in CRF. Kidney Int. 1990;38(6):1181-6.

25. Agudo RG, Rabih SA, Carro PG, Roldan FP, Vega $\mathrm{BP}$, Arias AA, et al. Gastrointestinal lesions in chronic kidney disease patients with anemia. Nefrologia. 2019;39(1):50-7.

26. Marinescu D, Lazar M, Zaharie S, Comanescu C, Tudoran C, Bica M, et al. Upper gastrointestinal bleeding in chronic kidney disease patients. Curr Heal Sci J. 2016;42(3):226-30.

27. Babitt JL, Lin HY. Mechanisms of anemia in CKD. J Am Soc Nephrol. 2012;23(10);1631-4.

28. Rios E, Beca F. Uremic Gastropathy. SpringerVerlag Berlin Heidelberg. 2014;674-6.

29. Lepere C, Cuillerier E, Van Gossum A, Bezet A, Schmit A, Landi B, et al. Predictive factors of positive findings in patients explored by push enteroscopy for unexplained Gl bleeding. Gastrointest Endosc. 2005;61(6):709-14.

30. Wilson D. Hematemesis, melena, and hematochezia. Clin Methods Hist Phys Lab Exam. 1990:439-42. 